\title{
Pengaruh Penggunaan Modul Berbasis Research pada Pembelajaran Think Pair Share dan Group Investigation terhadap Pemahaman Konsep dan Kemampuan Metakognisi Peserta Didik Kelas X SMA Negeri 1 Boyolali Tahun Ajaran 2013/2014
}

\author{
ARIEF RIDHO WICAKSONO *, SRI WIDORETNO, NURMIYATI \\ Pendidikan Biologi FKIP UNS, Jl. Ir. Sutami 36 A Kentingan Surakarta, Indonesia \\ *email: ariefridhow@yahoo.com
}

Manuscript received: 17 Desember 2014 Revision accepted: 25 Januari 2015

\begin{abstract}
The purpose of the research to determine effect of the use of Module-Based Research on Learning Model of Think Pair Share and Group Investigation to Understanding of Concept and Metacognition Ability of 10th Grade Students at SMA Negeri 1 Boyolali 2013/2014 Academic Year. This research was quasi experiment research which use Pretest-postest Nonequivalent control group design. The research population was all students of 10th Grade at SMA Negeri 1 Boyolali 2013/2014 Academic Year. The sample is taken by using Cluster Random Sampling method, in order to obtain 4 class experimental and 1 control class with the same capabilities. Experimental class is a class with treatment of different learning, namely TPS + module-based research, GI + module-based research, TPS, GI, and one class as a control. Data was collected using a multiple-choice test, test description, and observation sheets. Hypothesis testing using Anacova test. The research concluded that there are significant differences to understanding concept of students as a result of the use Think Pair Share and Group Investigation with module-based research. Results for metacognition abilities showed no significant difference from the treatment that used, namely TPS + module-based research, GI + module-based research, TPS, GI towards metacognitive abilities of of 10th Grade Students at SMA Negeri 1 Boyolali 2013/2014 Academic Year.
\end{abstract}

Keywords: Think Pair Share, Group Investigation, Module-Based Research, Understanding Concept, Metacognition Ability

\section{LATAR BELAKANG}

Pendidikan merupakan suatu proses yang mengikuti perubahan dan perkembangan jaman. Pendidikan berperan dalam berbagai aspek kehidupan seperti membantu meningkatkan potensi dan kemampuan peserta didik yang dikembangkan melalui proses belajar. Belajar menurut Hilgard adalah "learning is the process by which an activity originates throught training procedures (whether in laboratory or in natural environtments) as distinguished from changes by factor not attributable to training" (Riyanto, 2010). Makna belajar menurut Hilgard adalah latihan untuk melakukan sesuatu, sehingga yang bersangkutan menjadi berubah. Perubahan pada diri seseorang yang ditunjukkan dalam berbagai bentuk seperti perubahan pengetahuan, kecakapan, pemahaman sikap dan tingkah laku serta segala aspek yang ada pada individu melalui proses pembelajaran.

Proses pembelajaran dipengaruhi berbagai faktor salah satunya adalah media atau sumber belajar yang mendukung terjadinya proses belajar, sehingga tujuan dari proses pembelajaran tercapai. Sumber belajar merupakan segala sesuatu yang memudahkan peserta didik dalam memperoleh sejumlah informasi, pengetahuan, pengalaman, dan keterampilan melalui proses belajar mengajar. Contoh sumber belajar menurut Wiryokusumo dan Mustaji (1989) adalah lingkungan sekitar, slide, film, video, audio, majalah, bahan pengajaran terprogram dan modul. Modul sebagai sumber belajar digunakan untuk mengajak peserta didik berpikir secara aktif dan mandiri (Mulyasa, 2006).

Pembelajaran dengan modul mengajarkan learning by doing dan peserta didik diharapkan memiliki skills untuk menghadapi pemecahan masalah-masalah yang ditemukan dalam kehidupan sehari-hari melalui kegiatan didalam modul. Skills abad 21 yang diperlukan menurut Kay (2009) dan Dwyer (2013) adalah berpikir kritis, problem solving, mampu berkomunikasi, kolaborasi, kreatif, literasi sains dan memiliki kesadaran global, yang terintegrasi dalam pembelajaran. Pencapaian skills berpikir kritis, problem solving, mampu berkomunikasi, kolaborasi, kreatif, literasi sains dan memiliki kesadaran global diakomodasi oleh modul. Modul yang mengakomodasi skills yang diperlukan abad 21 adalah modul berbasis research.

Modul berbasis research memiliki 5 kelebihan menurut Summers \& Montani (1991), yaitu adanya perumusan tujuan, penyusunan hipotesis, pengumpulan data, analisis data dan menyimpulkan hasilnya. Berdasarkan kelebihan pada modul berbasis research memberikan pengalaman pada peserta didik untuk mengasah skills yang dimiliki dalam membangun konsep pemikirannya sendiri dan meningkatkan kemampuan metakognisi melalui kegiatan didalam modul berbasis research.

Pengetahuan metakognisi menurut Anderson \& Kathwohl, et al., (2001) adalah pengetahuan tentang 
kognisi yang secara umum sama dengan kesadaran dan pengetahuan tentang kognisi diri seseorang. Metakognisi mengacu pada pengetahuan tentang kognisi seperti pengetahuan tentang keterampilan (skills) dan strategi kerja yang baik untuk pembelajaran, mampu menggunakan keterampilan dan strategi kerja dengan tepat (Schraw \& Moshman, 1995). Metakognisi memiliki dua komponen, yaitu: 1) pengetahuan tentang kognisi dan 2) mekanisme pengendalian diri dan monitoring kognitif (Mohamad Nur, 2000), sehingga dikatakan bahwa metakognisi merupakan kesadaran tentang pengetahuan yang diketahui dan yang tidak diketahui. Strategi metakognisi merujuk pada cara meningkatkan kesadaran mengenai proses berpikir digunakan untuk merancang, memantau dan menilai sesuatu yang dipelajarinya. Hasil penelitian yang mendukung dilakukan oleh Beers (2009), menyatakan bahwa pada abad 21 peserta didik diharapkan mampu memahami dan mengatur proses berpikirnya melalui aktivitas metakognisi, sehingga merefleksikan struktur berpikir dan strategi berpikir efektif dalam pembelajaran. Efektifitas modul berbasis research yang digunakan dalam meningkatkan kemampuan metakognisi berdampak pada peningkatan hasil belajar kognitif peserta didik.

Hasil belajar kognitif berkolerasi dengan pemahaman konsep peserta didik yang menurut Hermawanto (2013) merupakan kemampuan mengerti, memahami, mengaplikasi, mengklasifikasi, generalisasi, mensintesis dan menyimpulkan objek-objek yang dipelajari. Peserta didik dikatakan memahami suatu konsep ketika mampu mengutarakan kembali konsep yang dipahami dengan menggunakan bahasanya sendiri. Kemampuan metakognisi mempengaruhi kemampuan kognitif peserta didik untuk memproses informasi yang diperoleh selama proses pembelajaran.

Pembelajaran yang memberdayakan keterampilan metakognisi yang mempengaruhi hasil belajar kognitif serta retensi secara signifikan dilakukan dengan menggunakan pembelajaran Think Pair Share (Ibe, 2009; Basith, 2011). Pembelajaran Think Pair Share memiliki tiga tahap utama yaitu: tahap berpikir mandiri (Think), tahap berpasangan (Pair) dan tahap berbagi (Share). Think Pair Share memberikan motivasi pada peserta didik untuk lebih aktif berpikir secara mandiri pada tahap think. Tahap pair peserta didik berpasangan dan berdiskusi dengan satu kelompok yang telah ditentukan oleh guru. Tahap share, hasil diskusi dibagi dengan semua kelompok di kelas (Slavin, 2005).

Pembelajaran Think Pair Share memberikan lebih banyak waktu untuk berpikir secara mandiri, menjawab, dan saling membantu satu sama lain yang diakomodasi melalui kegiatan dalam modul berbasis research, sehingga memberdayakan keterampilan metakognitif peserta didik (Basith, 2011). Think Pair Share membantu peserta didik lebih mudah dalam menemukan dan memahami konsep dalam pembelajaran. Pemahaman konsep yang lebih mudah disebabkan karena ada fase diskusi dalam kelompok yang heterogen diakomodasi oleh penggunaan modul berbasis research yang menyajikan fenomena nyata dalam kegiatannya.

Model pembelajaran lain yang meningkatkan kemampuan metakognisi melalui kegiatan diskusi, investigasi dan pemecahan masalah yang diakomodasi melalui penggunaan modul berbasis research selain pembelajaran Think Pair Share adalah pembelajaran Group Investigation. Hasil penelitian Sharan \& Sharan (1992) menyatakan bahwa pembelajaran Group Investigation memberikan pembelajaran bermakna melalui langkah penyelidikan ilmiah, sehingga membantu peserta didik belajar cara untuk belajar. Tahapan pembelajaran Group Investigation menurut Tan (2007) terdiri dari 6 tahapan yang meliputi pengelompokan (grouping), perencanaan (planning), penyelidikan (investigating), organisasi (organizing), mempresentasikan (presenting), evaluasi (evaluating). Group Investigation mengajak peserta didik berinteraksi dengan banyak informasi dan bekerja secara kolaborasi dalam situasi kooperatif untuk menyelidiki permasalahan, perencanaan dan melakukan presentasi, dan melakukan evaluasi hasil pekerjaan yang telah dilakukan (Listiana, 2013).

Evaluasi dari hasil pekerjaan yang telah dilakukan diperoleh melalui proses pencarian informasi, penyelidikan, analisis informasi yang digunakan untuk pemecahan masalah dan membuat keputusan berasal dari sumber belajar yang digunakan untuk memperoleh informasi. Modul berbasis research memberikan kegiatan untuk melakukan penyelidikan berdasarkan fakta nyata untuk menemukan solusi yang tepat. Kegiatan didalam modul berbasis research dapat menumbuhkan kemampuan metakognisi dan meningkatkan penguasaan konsep peserta didik. Kemampuan metakognisi dan pemahaman konsep materi yang dipelajari melalui Group Investigation digunakan untuk mengkonstruksi pengetahuan berdasarkan aktivitas dan pengalaman belajar pada saat memecahkan masalah.

\section{METODE}

Penelitian dilakukan di SMA Negeri 1 Boyolali kelas X pada semester genap tahun pelajaran 2013/2014. Populasi dalam penelitian adalah seluruh kelas X SMA Negeri 1 Boyolali tahun ajaran 2013/2014. Pengambilan sampel menggunakan cluster random sampling, sehingga diperoleh 4 kelas kelas eksperimen dan satu kelas kontrol yang memiliki kemampuan sama. Kelas eksperimen merupakan kelas dengan pemberian perlakuan pada pembelajaran yag berbeda, yaitu TPS + modul berbasis research, GI + modul berbasis research, TPS, GI dan satu kelas sebagai kontrol.

Variabel bebas pada penelitian adalah model pembelajaran yang digunakan disertai modul berbasis research serta variabel terikat yaitu pemahaman konsep dan kemampuan metakognisi peserta didik. Penelitian menggunakan teknik pengumpulan data menggunakan tes pilihan ganda untuk pemahaman 
konsep, tes uraian untuk kemampuan metakognisi, dan lembar observasi untuk ranah afektif

Instrumen penelitian berupa tes yang telah diujicobakan untuk mengetahui validitas, dan reliabilitas. Rancangan penelitian berupa Pretest-postest Nonequivalent control group design. Analisis data pada penelitian dengan menggunakan uji anacova dengan uji normalitas menggunakan uji Kolmogrov-Smirnov dan uji homogenitas dengan uji Levene's.

\section{HASIL DAN PEMBAHASAN}

Hasil analisis menunjukkan terdapat perbedaan yang signifikan terhadap pemahaman konsep dan kemampuan metakognisi pada masing-masing model pembelajaran (perlakuan) ditunjukkan dengan nilai signifikansi kurang dari 0,05 (Sig. $<0,05)$ yang secara rinci terlihat pada Tabel 1 untuk pemahaman konsep dan Tabel 2 untuk kemampuan metakognisi.

Tabel 1 Perbandingan Pemahaman Konsep antar MasingMasing Pembelajaran

\begin{tabular}{cccccc}
\hline \multirow{2}{*}{$\begin{array}{c}\text { Pembel } \\
\text { ajaran }\end{array}$} & \multicolumn{5}{c}{ Signifikansi } \\
\cline { 2 - 6 } & $\begin{array}{c}\mathrm{T} \\
\text { T }\end{array}$ & $\begin{array}{c}\text { TPS+ } \\
\text { MBR }\end{array}$ & $\begin{array}{c}\mathrm{G} \\
\mathrm{I}\end{array}$ & $\begin{array}{c}\text { GI+ } \\
\text { MBR }\end{array}$ & $\begin{array}{r}\mathrm{K} \\
\text { ontrol }\end{array}$ \\
\hline TPS & & $0,00^{*}$ & 0,37 & 0,088 & 0,366 \\
TPS+Modul & $0,00^{*}$ & & $0,00^{*}$ & $0,00^{*}$ & $0,00^{*}$ \\
GI & 0,37 & $0,00^{*}$ & & 0,4 & 0,075 \\
GI+Modul & 0,088 & $0,00^{*}$ & 0,04 & & 0,012 \\
Kontrol & 0,366 & $0,00^{*}$ & 0,075 & $0,012^{*}$ & \\
\hline
\end{tabular}

Ketetangan: * terdapat perbedaan signifikan $\left(\mathrm{H}_{0}\right.$ ditolak) MBR (Modul Berbasis Research)

Tabel 2 Perbandingan Kemampuan Metakognisi antar MasingMasing Pembelajaran

\begin{tabular}{lccccc}
\hline \multirow{2}{*}{ Pembelajaran } & \multicolumn{5}{c}{ Signifikansi } \\
\cline { 2 - 6 } & TPS & TPS+MBR & GI & GI+MBR & $\begin{array}{c}\text { Kontr } \\
\text { ol }\end{array}$ \\
\hline TPS & & $0,045^{*}$ & 0,461 & 0,557 & $0,00^{*}$ \\
TPS+Modu & & & 0,161 & 0,123 & $0,00^{*}$ \\
1 & $0,045^{*}$ & & & 0,886 & $0,00^{*}$ \\
GI & 0,461 & 0,161 & & & $0,00^{*}$ \\
GI+Modul & 0,557 & 0,123 & 0,886 & & \\
Kontrol & $0,00^{*}$ & $0,00^{*}$ & $0,00^{*}$ & $0,00^{*}$ & \\
\hline
\end{tabular}

Ketetangan: * terdapat perbedaan signifikan $\left(\mathrm{H}_{0}\right.$ ditolak) MBR (Modul Berbasis Research)

\section{Pemahaman Konsep}

Hubungan antara Model Pembelajaran dengan Pemahaman Konsep

Hasil perhitungan anacova menunjukkan nilai signifikansi kurang dari 0,05 (Sig.<0,05) yang berarti $\mathrm{H}_{0}$ ditolak. Penolakan $\mathrm{H}_{0}$ menunjukkan terdapat perbedaan yang signifikan antara model pembelajaran TPS, TPS + MBR, $G I, G I+M B R$, dan kontrol terhadap pemahaman konsep.
Rerata dari masing-masing model pembelajaran yang digunakan dalam penelitian seperti pada Tabel 3

Tabel 3 Rerata Pemahaman Konsep pada Model Pembelajaran TPS, TPS + MBR, GI, GI + MBR, dan Kontrol

\begin{tabular}{ccccc}
\hline TPS & TPS+MBR & GI & GI+MBR & Kontrol \\
\hline 66,05 & 77,2 & 62 & 60 & 62,75 \\
\hline
\end{tabular}

Keterangan: MBR (Modul Berbasis Research)

Berdasarkan Tabel 1 diketahui bahwa perbedaan signifikan terdapat antara model pembelajaran dengan bantuan modul dan model pembelajaran tanpa bantuan modul terhadap pemahaman konsep. Perbandingan rerata antara masing-masing model pembelajaran seperti pada Tabel 3 diketahui bahwa pembelajaran TPS + modul memiliki rerata tertinggi dengan nilai 77,2 sedangkan terendah diperoleh pada pembelajaran GI + MBR

Pemahaman konsep menurut Pea (1993) diperoleh melalui kegiatan peserta didik, karena kegiatan yang telah dilakukan ditafsirkan dalam suatu sistem pemikiran sehingga mendapatkan interpretasi dari suatu konsep yang dipelajari. Pemahaman konsep diperoleh melalui aktivitas bertukar pikiran antar peserta didik sehingga setiap peserta didik saling mengemukakan hasil pemikiran yang telah didiskusikan dengan bahasa berbeda, berdasarkan makna dari hasil diskusi yang dikomunikasikan (Miller, 1997). Pembelajaran yang mengakomodasi peserta didik untuk saling berkomunikasi dan bertukar pikiran salah satunya adalah pembelajaran Think Pair Share dan Group Investigation

\section{Hubungan antara Model Pembelajaran Tanpa} Menggunakan Modul Berbasis Research dengan Model Pembelajaran Menggunakan Modul Berbasis Research Terhadap Pemahaman Konsep.

Model Pembelajaran Tanpa Menggunakan Modul Berbasis Research

Model pembelajaran yang digunakan tanpa menggunakan bantuan modul adalah model pembelajaran Think Pair Share dan Group Investigation. Hasil rerata dari kedua model pembelajaran yang digunakan kemudian dibandingkan dengan kelas kontrol seperti pada Tabel 4

Tabel 4 Rerata Pemahaman Konsep Pada Model Pembelajaran TPS, GI, dan Kontrol

\begin{tabular}{ccc}
\hline TPS & Kontrol & GI \\
\hline 65,05 & 62,75 & 62
\end{tabular}

Berdasarkan aplikasi model pembelajaran tanpa bantuan modul diperoleh rerata pemahaman konsep seperti pada Tabel 4. Rerata pada Tabel 4 menunjukkan bahwa pembelajaran TPS (Think Pair Share) memiliki rerata tertinggi 65,05, diikuti pembelajaran kontrol dengan rerata pemahaman konsep 62,75 dan terendah adalah pembelajaran Group Investigation dengan rerata pemahaman konsep 62. Bila dilihat dari rerata 
pemahaman konsep, pembelajaran Think Pair Share memiliki rerata tertinggi, namun dilihat dari nilai signifikansi pada Tabel 1 menunjukkan bahwa pemahaman konsep Think Pair Share tanpa modul tidak berbeda signifikan dengan pembelajaran Group Investigation dan pembelajaran kontrol. Kondisi yang sama terjadi pada pembelajaran Group Investigation tanpa menggunakan modul tidak berbeda signifikan dengan pembelajaran kontrol terhadap terhadap pemahaman konsep peserta didik.

Pemahaman konsep peserta didik dipengaruhi oleh kemampuan bekerjasama dalam berdiskusi dan kemampuan berkomunikasi (Miller, 1997). Hasil yang diperoleh berdasarkan Tabel 1 dan Tabel 4 menunjukkan bahwa pembelajaran Think Pair Share tanpa menggunakan modul memiliki kualitas diskusi dan komunikasi yang sama dengan pembelajaran Grup Investigation dan pembelajaran kontrol dalam mengakomodasi pemahaman konsep peserta didik. Hal serupa ditunjukkan pada pembelajaran Grup Investigation tanpa menggunakan modul memiliki kualitas yang sama dalam berdiskusi dan berkomunikasi dibandingkan dengan pembelajaran kontrol dalam mengakomodasi pemahaman konsep peserta didik. Kualitas pembelajaran Think Pair Share, Group Investigation dan kontrol yang sama dilihat dari rerata pemahaman konsep pada Tabel 4 memiliki nilai yang tidak jauh berbeda. Berdasarkan rerata pemahaman konsep peserta didik terlihat bahwa pembelajaran Think Pair Share dan Group Investigation tanpa menggunakan modul tidak memberi perbedaan yang berarti terhadap pemahaman konsep peserta didik.

Kemampuan bekerjasama, berdiskusi dan berkomunikasi dalam kelompok dianggap penting karena mengakomodasi kemampuan berpikir peserta didik dalam menyelesaikan masalah secara bersama-sama berdasarkan kegiatan yang dilakukan. Peserta didik didorong untuk mencari solusi yang tepat dalam memecahkan masalah sehingga peserta didik membangun pemikirannya sendiri (Lam, 2005). Pembelajaran daengan berdiskusi dan berkomunikasi juga mengajak peserta didik untuk mengkomunikasikan hasil pemikiran, saling merespon dan bekerja secara bersama-sama dalam menyelesaikan masalah, sehingga peserta didik lebih mudah dalam memahami materi yang dipelajari (Leikin \& Zaslavsky, 1997).

\section{Model Pembelajaran Menggunakan Modul Berbasis}

Research

Hasil perhitungan statistik menunjukkan perbedaan rerata dari model pembelajaran dengan menggunakan modul berbasis research dibandingkan dengan kelas kontrol secara rinci terlihat pada Tabel 5.

Tabel 5 Rerata Pemahaman Konsep pada Model Pembelajaran TPS + MBR, GI + MBR, Kontrol

\begin{tabular}{ccc}
\hline TPS + MBR & Kontrol & GI + MBR \\
\hline 77,2 & 62,75 & 60
\end{tabular}

Rerata pemahaman konsep pada Tabel 5 menunjukkan pembelajaran $G I+M B R$ memiliki rerata terendah yaitu 60 diikuti dengan pembelajaran kontrol 62,75 , dan tertinggi adalah model pembelajaran TPS + MBR dengan rerata 77,2. Berdasarkan Tabel 1 diketahui bahwa model pembelajaran yang menggunakan modul berbasis research berbeda signifikan terhadap pemahaman konsep. Pemahaman konsep pembelajaran TPS + MBR berbeda signifikan dengan pembelajaran GI + MBR dan kontrol. Kondisi sama terjadi pada pemahaman konsep pembelajaran GI + MBR yang berbeda signifikan dengan pembelajatan kontrol. Dilihat dari rerata Tabel 5 penggunaan modul paling optimal terhadap pemahaman konsep digunakan pada pembelajaran Think Pair Share.

Pembelajaran Think Share Pair dengan menggunakan modul berbasis research memiliki hasil yang optimal terhadap pemahaman konsep, karena modul berbasis research memiliki scientific method seperti perumusan tujuan, penyusunan hipotesis, pengumpulan data, analisis data dan menyimpulkan hasil (Summers \& Montani, 1991). Pembelajaran Think Pair Share dengan menggunaan modul berbasis research memberikan pengalaman secara langsung melalui kegiatan yang terdapat didalam modul. Pengalaman secara langsung dalam kegiatan belajar mengarahkan peserta didik mengkonstruksi pengetahuan berdasarkan pengalaman yang dilakukan. Konstruksi pengetahuan menurut Akyol dan Garrison (2011) memiliki empat tahapan utama yaitu identifikasi, eksplorasi, integrasi, resolusi. Tahap identifikasi adalah kegiatan peserta didik mengidentifikasi atau mendefinisikan permasalahan yang dipelajari. Tahap eksplorasi adalah sebuah proses peserta didik mengeksplorasi secara individual dan bersama-sama informasi dan ide-ide yang mungkin memberikan wawasan tentang masalah yang dipelajari. Tahap integrasi mendorong peserta didik membangun makna dari ide-ide yang dihasilkan. Tahap resolusi adalah tahap peserta didik secara kolaboratif mengkonfirmasi solusi untuk masalah yang dipelajari sehingga peserta didik mampu membangun makna dari pendidikan kolaboratif dengan pengalaman dalam kegiatan pembelajaran.

Pembelajaran Think Pair Share mengajak peserta didik berfikir secara mandiri dengan mengeksplorasi pengetahuannya seperti terlihat pada sintak Think. Pada tahap Pair peserta didik terlibat aktif dalam proses pembelajaran untuk memecahkan masalah dalam kegiatan pembelajaran, karena peserta didik saling berinteraksi dan bekerja sama dalam kelompok. Tahap Share peserta didik diminta untuk berbagi hasil diskusi dengan menggunakan bahasanya sendiri. Sintak yang dimiliki Think Pair Share mengembangkan kecerdasan logis peserta didik secara optimal untuk saling bertukar pikiran dalam memecahkan permasalahan pada saat kegiatan belajar mengajar (Nurlaila dan Buditjahjanto, 2013).

Pembelajaran Think Pair Share mengakomodasi lebih banyak waktu untuk berpikir secara mandiri, menjawab, dan saling membantu dalam menyelesaikan kegiatan dalam pembelajaran yang langsung diperoleh melalui 
kegiatan dalam modul. Kegiatan pembelajaran menggunakan modul berbasis research menciptakan pembelajaran yang bermakna dan melekat pada ingatan jangka panjang peserta didik karena informasi yang didapat tertata dengan baik (Banikowski, 1999). Kegiatan pembelajaran yang dilakukan mengajak peserta didik untuk mengenal masalah, menemukan cara-cara yang dapat dipakai untuk memecahkan masalah-masalah, mengumpulkan dan menyusun informasi yang diperlukan, memahami serta menggunakan bahasa yang jelas, menganalisis data, dan menarik kesimpulan (Suraya, Subagia, Tika, 2014).

\section{Kemampuan Metakognisi}

Hubungan antara Model Pembelajaran dengan

Kemampuan Metakognisi

Kemampuan metakognisi dalam pembelajaran Think Pair Share, Think Pair Share dibantu modul berbasis research, Group Investigation, Group Investigation dibantu modul berbasis research dan pembelajaran kontrol memiliki perbedaan yang signifikan. Perbedaan signifikan ditunjukkan pada Tabel 2 dengan nilai signifikansi kurang dari 0,05 (Sig.<0,05) yang berarti $\mathrm{H}_{0}$ ditolak. Perbedaan signifikan kemampuan metakognisi terlihat melalui nilai rerata kemampuan metakognisi seperti terlihat pada Tabel 6.

Tabel 6. Rerata Kemampuan Metakognisi pada Model Pembelajaran TPS, TPS + MBR, GI, GI + MBR, dan Kontrol

\begin{tabular}{ccccc}
\hline TPS & TPS+MBR & GI & GI+MBR & Kontrol \\
\hline 40,19 & 45,18 & 41,94 & 41,73 & 53,96 \\
\hline
\end{tabular}

Keterangan: MBR (Modul Berbasis Research)

Perbandingan nilai rerata kemampuan metakognisi pada Tabel 6 menunjukkan pembelajaran di kelas kontrol memiliki rerata yang paling baik dengan nilai 53,96, diikuti TPS+MBR dengan rerata 45,18, pembelajaran GI dengan rerata 41,94 , pembelajaran GI+MBR dengan rerata 41,73, dan terendah pembelajaran TPS dengan rerata 40,19. Berdasarkan hasil pada Tabel 2 terlihat bahwa pembelajaran kontrol yaitu pembelajaran yang biasa dilakukan pada pelajaran biologi memberi perbedaan yang signifikan terhadap kemampuan metakognisi peserta didik. Perbedaan yang signifikan kemampuan metakognisi antara pembelajaran kelas kontrol dengan kelas perlakuan disebabkan karena pembelajaran kontrol yang digunakan merupakan pembelajaran yang mengacu pada kurikulum 2013. Pembelajaran menggunakan kurikulum 2013 mengharuskan peserta didik untuk terlibat aktif dalam pembelajaran, mulai dari diskusi, pengamatan, perencanaan, praktek langsung dilapangan dan pemecahan masalah.

Kemampuan metakognisi menurut Anderson \& Kathwohl, et al., (2001) adalah pengetahuan tentang kognisi yang secara umum sama dengan kesadaran dan pengetahuan tentang kognisi diri seseorang. Kemampuan metakognitif membantu peserta didik menjadi self- regulated learner yang bertanggung jawab terhadap kemajuan belajarnya sendiri dan mengadaptasi strategi belajarnya untuk mencapai tujuan pembelajaran (Efklides, 2011). Metakognisi tidak selalu mengenai "thoughts about thoughts", tetapi meliputi pengetahuan seseorang dalam pemrosesan informasi serta keadaan kognitif, afektif, dan cara seseorang memonitor pengetahuan yang dimiliki (Louca, 2003).

Kemampuan metakognisi bukan merupakan kegiatan internal individu semata, tetapi mencakup kegiatan komunikasi, kegiatan menjelaskan, dan membenarkan pemikiran seseorang terhadap dirinya sendiri dan orang lain (Flavel, 1987). Kemampuan metakognisi menurut Koutselini (1991) dikembangkan melalui pembelajaran yang mendorong peserta didik untuk berpikir keras, fokus untuk memahami masalah yang harus dipecahkan, mencari strategi untuk mengatasi permasalahan, mendorong peserta didik untuk bertanya dalam kegiatan pembelajaran (Louca, 2003).

\section{b. Hubungan antara Model Pembelajaran Tanpa Menggunakan Modul Berbasis Research dengan Model Pembelajaran Dibantu dengan Modul Berbasis Research Terhadap Kemampuan Metakognisi Model Pembelajaran Tanpa Menggunakan Modul} Berbasis Research

Pengaruh model pembelajaran tanpa menggunakan modul berbasis research terhadap kemampuan metakognisi peserta didik dilihat dari rerata yang diperoleh secara rinci terlihat pada Tabel 7 .

Tabel 7 Rerata Kemampuan Metakog-nisi Pada Model Pembelajaran TPS, GI, dan Kontrol.

\begin{tabular}{ccc}
\hline TPS & Kontrol & GI \\
\hline 40,19 & 53,96 & 41,94 \\
\hline
\end{tabular}

Perhitungan statistik rerata kemampuan metakognisi menunjukkan pembelajaran kelas kontrol hasil terbaik dengan rerata 53,96, diikuti pembelajaran GI dengna rerata 41.94 dan terendah pembelajaran TPS dengan rerata 40,19. Hasil perhitungan kemampuan metakognisi pada Tabel 2 menunjukkan model pembelajaran Kontrol berbeda signifikan dibandingkan dengan pembelajaran TPS dan GI tanpa menggunakan modul. Perbedaan yang terjadi menunjukkan bahwa pembelajaran kontrol memiliki kualitas yang lebih baik dalam mengakomodasi kemampuan metakognisi peserta didik dibandingkan pembelajaran TPS dan GI. Kelas kontrol lebih optimal dalam mengakomodasi kemampuan metakognisi karena memiliki scientific method sesuai dengan kurikulum 2013.

Peserta didik dapat meningkatkan kemampuan metakognisi melalui pemikiran mereka sendiri pada saat membaca, menulis dan memecahkan masalah di sekolah (Louca, 2003). Kemampuan metakognisi mencakup kemampuan untuk berkomunikasi dan mendiskusikan ideide dalam menyelesaikan permasalahan yang dipelajari (Brown, 1987). Kegiatan diskusi dan berkomunikasi 
diakomodasi dengan baik melalui pembelajaran kontrol yang mengajak peserta didik untuk terlibat aktif dalam pembelajaran, mulai dari diskusi, pengamatan, perencanaan, praktek langsung dilapangan dan pemecahan masalah.

\section{Model Pembelajaran Menggunakan Modul Berbasis}

\section{Research}

Pengaruh model pembelajaran menggunakan modul berbasis research terhadap kemampuan metakognisi peserta didik dilihat dari nilai rata-rata yang diperoleh secara rinci terlihat pada Tabel 8.

Tabel 8 Rerata Kemampuan Metakog-nisi Pada Model Pembelajaran TPS + MBR, GI + MBR, dan Kontrol

\begin{tabular}{ccc}
\hline TPS+MBR & Kontrol & GI+MBR \\
\hline 45,18 & 53,96 & 41,73 \\
\hline
\end{tabular}

Keterangan: MBR (Modul Berbasis Research)

Perhitungan statistik kemampuan metakognisi dilihat dari rerata pada Tabel 8 menunjukkan pembelajaran dengan menggunakan modul berbasis research tidak memberi perbedaan terhadap kemampuan metakognisi pada peserta didik dengan rerata lebih rendah daripada kelas kontrol. Rerata kemampuan metakognisi terendah pada pembelajaran GI+MBR dengan rerata 41,73 , diikuti pembelajaran TPS+MBR dengan rerata 45,18 dan tertinggi pada pembelajaran kontrol dengan rerata 53,96. Perbedaan signifikan ditunjukkan kelas kontrol dibandingkan pembelajaran TPS+MBR dan GI+MBR yang secara rinci dapat dilihat pada Tabel 2 memperlihatkan nilai signifikan kurang dari 0,05 (Sig.<0,05). Berdasarkan hasil yang diperoleh diketahui bahwa model pembelajaran TPS+MBR dan GI+MBR tidak memberikan perbedaan yang signifikan pada kemampuan metakognisi peserta didik.

Hasil penelitian Zen (2010) dan Basith (2011) menunjukkan bahwa pembelajaran Think Pair Share dan Group Investigation mampu memberdayakan keterampilan metakognitif yang berhubungan dengan kemampuan metakognisi peserta didik. Kondisi sebaliknya terjadi pada aplikasi dilapangan, karena pada aplikasi dilapangan menunjukkan pembelajaran kontrol memiliki pengaruh yang signifikan terhadap kemampuan metakognisi peserta didik dibanding model pembelajaran TPS, TPS + Modul, GI, GI + Modul yang diterapkan. Perbedaan terjadi disebabkan faktor-faktor diluar variabel penelitian, seperti motivasi, pribadi siswa, dan lingkungan (Winkel, 2004). Pengaruh motivasi menurut Slavin (1996) terdapat pada motivasi belajar yang meningkat pada saat peserta didik menunjukkan persaingan yang tinggi dalam belajar, sehingga setiap kelompok memiliki motivasi untuk terlihat lebih baik dibanding kelompok lain (Fauziyah, 2013). Pribadi siswa berpengaruh pada kemampuan intelektual yang memegang penting terhadap prestasi belajar siswa, khususnya dalam pelajaran Sains (Winkel, 2004). Lingkungan mempengaruhi hasil belajar karena semakin kondusif suasana belajar, semakin baik hasil belajar yang didapatkan. SMA 1 Boyolali memiliki suasana belajar mengajar yang baik dan kondusif dengan didukung sarana dan prasarana yang menunjang pembelajaran. Pembelajaran di SMA 1 Boyolali mengikuti kurikulum 2013 sehingga pembelajaran yang dilakukan sesuai dengan kurikulum 2013. Kelas kontrol dalam aplikasi dilapangan sesuai dengan pembelajaran setiap hari di SMA 1 Boyolali yaitu dengan mengajak siswa terlibat aktif dalam pembelajaran, mulai dari diskusi, pengamatan, perencanaan, praktek langsung dilapangan dan pemecahan masalah. Pembelajaran berbasis scientific pada kurikulum 2013 menyebabkan kelas kontrol memiliki nilai metakognisi lebih baik didalam pembelajaran.

Kemampuan metakognisi menurut Koutselini (1991) dikembangkan melalui pembelajaran yang mendorong peserta didik untuk berpikir keras, fokus untuk memahami masalah yang harus dipecahkan, mencari strategi untuk mengatasi permasalahan, mendorong peserta didik untuk bertanya dalam kegiatan pembelajaran (Louca, 2003). Kemampuan metakognisi mengacu pada pengetahuan tentang kognisi seperti pengetahuan tentang keterampilan (skills) dan strategi kerja yang baik untuk pembelajaran, mampu menggunakan keterampilan dan strategi kerja dengan tepat untuk mencapai tujuan pembelajaran. Regulasi metakognisi mengacu pada kegiatan-kegiatan yang mengontrol keterampilan seperti merencanakan, memonitor pemahaman, dan mengevaluasi (Schraw \& Moshman, 1995).

\section{KESIMPULAN}

Berdasarkan hasil penelitian disimpulkan:

1. Penggunaan modul berbasis research pada pembelajaran Think Pair Share berpengaruh signifikan terhadap pemahaman konsep peserta didik.

2. Penggunaan modul berbasis research pada pembelajaran Think Pair Share dan Group Investigation tidak berpengaruh signifikan terhadap kemampuan metakognisi peserta didik.

\section{DAFTAR PUSTAKA}

Anderson, L. W. (2001.). A Taxonomy for Learning, Teaching, and Assessing: A Revision of Bloom's Taxonomy of Educational Objective. USA: Addison Wesley Longman,Inc.

Aunurrahman. (2010). Belajar dan Pembelajaran. Bandung: Alfabeta.

Awang, T. S. (2012). Modul for Learning Integral Calculus With Maple: Lecturer's Views. The Turkish Online Journal of Education Technology, 234-245.

Banikowski, A. K. ( 1999). Strategies to Enhance Memory Based On Brain-Research. Focus on Exceptional Children. 
Basith, A. (2011). Hubungan Keterampilan Metakognitif dan Hasil Belajar Matapelajaran IPA pada Siswa Kelas IV SD dengan Strategi Pembelajaran Jigsaw dan Think Pair Share (TPS). Malang: UM.

Beers, S. Z. (2009). 21st Century Skills. Preparing Students for Their Future. Science Technology Engineering Math, 1-6.

Blakey, E. -S. (1990). Developing Metacognition.Y. New York: ERIC Clearinghouse on Information Resources Syracuse $\mathrm{N}$.

Curwen, M. S. (2010). Increasing Teachers' Metacognition Develops Students' Higher Learning during Content Area Literacy Instruction: Finding from the Read-Write Cycle project. Issues in Teacher Education, 151-157.

Dawyer, C. P. (2013). An integrated critical thinking framework for the 21stcentury. Thinking Skills and Creativity, 43-52.

Efklides, A. (2011). Interactions of Metacognition With Motivation. School of Psychology, 6-25.

Flavell, J. H. (1979). Metacognition and Cognitive Monitoring, A New Area of Cognitive-Developmental Inquiry. American Psychologist, 906-911.

Gagne, R. M. (1988). In H. \&. Manan, Prinsip-Prinsip Belajar Untuk Pengajaran (Essential of learning for Instruction). Surabaya: Usaha Nasional.

Gama, A. C. (2004). Integrating Metacognition Instruction in Interactive Learning Environments. Brighton, UK: University of Sussex.

Hermawanto, S. K. (2013). Pengaruh Blended Learning terhadap Penguasaan Konsep dan Penalaran Fisika Peserta Didik Kelas X . Jurnal Pendidikan Fisiska Indonesia, 67-76.

Ibe, H. N. (2009). Metacognitive Strategies on Classroom Participation and Student Achievement in Senior Secondary School Science Classrooms. Science Education International, 25-31.

Kay, K. (2009). Middle School Preparing Young People for 21st Century Life and Work . Middle School Journal, 41-45.

Listiana, L. (2013). Pemberdayaan Keterampilan Berpikir dalam Pembelajaran Biologi Melalui Model Kooperatif Tipe GI (GROUP INVESTIGATION) dan TTW (THINK, TALK, WRITE). Surabaya: Universitas Muhammadiyah Surabaya.

Livingston, J., (1997). Metacognition: An overview. Retrieved Jan. 2, 2013 from HYPERLINK "http://www.gse.buffalo.edu/fas/shuell/cep564/Metacog.ht m" http://www.gse.buffalo.edu/fas/shuell/cep564/ Metacog.htm

Louca, E. P. (2003). Metacognition and Theory of Mind Newcastle: Cambridge Scholars Publishing.

Mulyasa, E. (2006). Kurikulum Berbasis Kompetensi. Bandung : Remaja Rosda Karya.

Nur, M. (2000). Pengajaran Berpusat Kepada Siswa dan Pendekatan Konstruktivis Dalam Pengajaran. Pusat Pendidikan Sains dan Matematika Sekolah. Surabaya: Unesa .

Purnomo, A. (2013). Peningkatan Kemampuan Berpikir Kritis Siswa dengan Penerapan Model Pembelajaran Kooperatif Tipe TPS (THINK PAIR SHARE) Dalam Pembelajaran
IPS di Sekolah Dasar. Surabaya: Universitas Negeri Surabaya.

Purwanto, N. (1994). Prinsip-prinsip dan Teknik Evaluasi Pengajaran. Bandung: PT. Remaja Rosdakarya.

Rahman, S. \&. (2006). Hubungan antara Kesadaran Metakognisi, Motivasi dan Pencapaian Akademik Pelajar Universiti. Jurnal Pendidikan, 21-39.

Riyanto, Y. (2010 ). Paradigma Baru Pembelajaran Sebagai Referensi bagi Pendidik dalam Implementasi Pembelajaran yang Efektif dan Berkualitas. Jakarta: Kencana Prenada Media Group.

Rustaman, N. (2005). Strategi Belajar Mengajar Biologi. Malang: Universitas Negeri Malang.

Sagala, S. (2004). Konsep dan Makna Pembelajaran. Bandung: Alfabeta.

Schraw, G. \& Moshman, D. (1995). Metacognitive Theories. Educational Psychology Review, 351-371.

Sharan, Y. \& Sharan, S. (1992). Group Investigation: Expanding cooperative Learning. New York: Teacher College Pres.

Slavin, R. E. (2005). Cooperative Learning, Teori, Riset dan Praktik. Bandung: Nusa Media.

Summers, R. L. (1998). Research curriculum for residents based on the structure of the scientific method. Medical Teacher, 35-37.

Syafii, W. \& Yasin, R. M. (2013). Problem Solving Skills and Learning Achievements through Problem Based Module in Teaching and Learning Biology in High School. Asian Sosial Science, 220-228.

Tan, I. G. C., Lee, C.K.E. \& Sharan, S. (2007). Group investigation effects on achievement, motivation, and perceptions of students in Singapore. The Journal of Educational Research, 100

Trianto. (2007). Model-Model Pembelajaran Inovatif Berorientasi Konstruktivistik. Jakarta: Prestasi Pustaka Publisher.

Winkel, W. S. (2004). Psikologi Pengajaran. Jakarta: Grasindo.

Wiryokusumo \& Mustaji, I. (1989). Pengelolaan Sumber Belajar. Surabaya: University Press IKIP Surabaya.

Woolfolk, A. (2010). Educational Psychology. Upper Saddle River: Pearson Education International.

Zaromb, F. M. (2010). Comprehension as a Basis for Metacognitive Judgments:Effects of Effort After Meaning on Recall and Metacognition. Journal of Experimental Psychology: American Psychological Association Learning. Memory, and Cognition, 552-557.

Zen, A. R. (2010). Hubungan Keterampilan Metakognitif dan Hasil Belajar Siswa Kelas IV Sekolah Dasar (SD) dalam Pembelajaran Sains pada Penerapan Strategi Pembelajaran Problem Based Learning (PBL) dan Inkuiri. Skripsi tidak diterbitkan. Malang: Jurusan Biologi FMIPA UM

Zimmerman, B. (2008). Investigating self-regulation and motivation: historical background, methodological developments, and future prospects. American Educational Research Journal, 166 -183. 